\title{
Regional Security Community in the Western Balkans: A Cross-Comparative Analysis ${ }^{1}$
}

\author{
REBECCA J. CRUISE* \\ University of Oklahoma, USA \\ SUZETTE R. GRILLOT \\ University of Oklahoma, USA
}

\begin{abstract}
Many have observed the early phases of regional security community development in the Western Balkans over the past decade. Much of this research has focuses on elite-level, government to government and government to International Organization cooperation. Yet, for security community to become a reality, it must also develop at the public-level. In the Western Balkans, it remains to be seen just how deep this new sense of community reaches. Based on fieldwork and surveys conducted in 2007 and 2008, a crucial moment for the region, we argue that public-level security community is inconsistent and in some areas is all together lacking. It is our position that programs advanced in the Western Balkans must concentrate not just on elite institution building, but also on community building within and between the individual countries of the region.
\end{abstract}

Keywords: security community, Western Balkans, public opinion, regional identity

\section{Introduction}

It has long been recognized that an enhanced sense of cooperation, trust and reciprocity among and between countries, what is often termed a security community, is important for maintaining peace. ${ }^{2}$ Members of a security community view each other as partners, with the thought of violent conflict between them almost unthinkable. Therefore, the recognition of commonality and enhanced partnership among the governments of a post-

1 Research for this study was generously supported by IREX and the University of Oklahoma Research Council.

2 Deutsch 1964; Adler and Barnett 1998; Grillot et al 2010.

*rebeccajcruise@ou.edu 
conflict region such as the Western Balkans is positive and represents a crucial process for creating a lasting peace in the region and in the European neighborhood. ${ }^{3}$

Scholars observed the early phases of regional security community development in the Western Balkans over the past decade. Yet, much of this literature has focused on the increase in elite-level, government to government and government to International Organization (IO) communication and cooperation. ${ }^{4}$ The role of external actors in encouraging an environment for security community to develop is significant, as are the actions of elite-level policy makers in enhancing cooperation. However, for security community to become a reality, it must alsto develop at the public-level. ${ }^{5}$ In the Western Balkans, it remains to be seen just how deep this new sense of community reaches. Therefore, here we assess the development of public-level, regional security community based on the perceptions of average people in the Western Balkans. Our findings suggest that public-level security community is inconsistent and in some areas is all together lacking. Given the many benefits of security community, it is our position that activities in the Western Balkans advanced by IOs, Non-Governmental Organizations (NGOs) and local groups must concentrate not just on institution building, but also on community building within and between individual countries in the region.

\section{Security Community}

Theories of security community stem predominantly from Karl Deutsch's notion of "pluralistic security community," which involves states coming together to cooperate on issues of mutual security. ${ }^{6}$ This is not simply a matter of aiming to enhance physical and military security, it is an understanding among partners that they are similar and that they have common concerns. Members of a security community operate based on "mutual responsiveness." Their shared identity, sense of sympathy, loyalty and "we-feeling" allows members to predict each other's behavior and cooperate accordingly. ${ }^{7}$ When in place, such conditions make violent behavior among and between security community members much less likely as they seek peaceful resolutions to security problems. ${ }^{8}$

3 The Western Balkans is defined as the Former Yugoslavia plus Albania and minus Slovenia. Therefore, the region includes Albania, Bosnia and Herzegovina, Croatia, Kosovo (territory), Macedonia, Montenegro and Serbia. We use this delineation because it is used by the European Union (http://eeas.europa.eu/western_balkans/index_en.htm). Other labels, such as the "Balkans" (includes Romania and Bulgaria) and "Southeastern Europe" (generally includes Greece Turkey), are also used in various contexts to describe the region (Bechev 2006). It should be noted that both Yugoslavia and Western Balkans are labels created by external parties, indicating the importance of $3^{\text {rd }}$ party players in the region historically and today.

4 Bechev 2011; Grillot et al 2010; Kavalski 2006.

5 Belloni 2009, 313-331.

6 Deutsch 1957, 5.

7 Adler 1991.

8 Adler and Barnett 1996, 67-68; Wendt 1992, 395-421. 
We build upon Deutsch's theory of pluralistic security community and include a focus on public-level security community formation. ${ }^{9}$ Examining the public side of security community formation potentially offers greater depth to theories of security community in general, and it may help inform peaceful resolution strategies for other post-conflict areas. More specifically, acknowledging the public-level addresses the ethnic and religious conflicts that continue in and among the Western Balkan countries despite government progress toward membership in prestigious IOs.

Security community at the public-level involves a shared sense of identity and purpose among the citizenry that leads to expectations of peaceful change. Such a concept is inherently slippery to define and establish. However, the importance of considering security community among the public remains critical to our understanding of elitelevel community trickle down effects, or conversely, to what extent the public-level poses significant obstacles to elite efforts in post-conflict areas.

To study security community development, Adler suggests using a tiered system. Tier I is where states begin to "orient toward each other." There is a marked increase in interactions and early realizations of joint concerns and possible gains. As the relationship develops, it moves into Tier II. At this level there is consistent interaction on a wide range of topics. Finally, when security community is achieved, there exists collaboration among groups or states and there is a sense of common identity, mutual trust and an expectation of reciprocity. It is at this fully developed stage, that the prospects for peace are greatest. ${ }^{10}$

In an effort to further specify, Adler argues that security community tiers develop in separate, not necessarily linear, phases. In the first, or "nascent" phase, states show tier one characteristics and begin to show signs of tier two development. ${ }^{11}$ Kavalski explains that this nascent phase or "embryonic" stage is one that is characterized strictly by elitelevel security community. ${ }^{12}$ The "ascendant" phase comes next. In this phase, all of tier two characteristics are present and there is evidence that connections are becoming tighter and deeper. In the second phase, some of the tier three expectations also emerge. Finally in the "mature" phase, we can say that a security community is fully developed. ${ }^{13}$

9 In his earlier work, Deutsch discusses measuring pluralistic security community by exploring transaction flows among populations. We, however, are interested in going further to explore the public perceptions and opinions effecting and being affected by these interactions.

10 Adler 1992; Adler 1991.

11 Ibid.

12 Kavalski 2008, 6.

13 Adler and Barnett 1998, 53-55. 
Table 1: Security Community Tiers of Development

\begin{tabular}{|l|l|l|}
\hline Phase & Tiers & Development \\
\hline Nascent & $\begin{array}{l}\text { All of Tier I, some of Tier II } \\
\text { present }\end{array}$ & Beginning interaction \\
\hline Ascendant & $\begin{array}{l}\text { All of Tier II, possibly some } \\
\text { of Tier III present }\end{array}$ & Tighter relationship, which strengthens over time. \\
\hline Mature & Tier III present & $\begin{array}{l}\text { Security community is developed and stable. Violence } \\
\text { no longer a viable option for the resolution of conflict. }\end{array}$ \\
\hline
\end{tabular}

\section{Methodology}

Research for this project was primarily carried out in 2007 and 2008. This was a critical time in the Western Balkans as momentum was building and enthusiasm for Euro-Atlantic organization membership was high. During that time, conditions were especially favorable for security community growth. ${ }^{14}$ Our research was conducted as Kosovo declared its independence and just before Croatia and Albania became members of NATO. To some degree all states of the region had the same goals and were in similar positions. By the end of 2008, the situation had changed. The effects of the global economic crisis had reached the area, leading to enhanced internal issues and some reticence by the international community to exert efforts away from home. ${ }^{15}$ Therefore, 2008 is a good reference point for this assessment of security community because it allows us to explore public opinion at an optimal time, but it also gives us some distance from which to assess our findings.

Our findings come from interviews, news stories and official communications from local governments and IOs. We also contracted with local research institutions to conduct telephone surveys in each of the seven Western Balkan countries (territories). ${ }^{16}$ Our intention with the surveys was to assess the sense of security community among average people. ${ }^{17}$ Therefore, our surveys focused on perceptions of a sense of a Western Balkans identity and the feelings of internal cohesion within domestic populations. ${ }^{18}$ Finally, security community is theoretically designed to prevent violence, so a component of our surveys asked respondents their opinions regarding the prospects for peace.

14 Bieber 2012.

15 Mameli 2011.

16 Telephone surveys were conducted in Macedonia and Serbia during the summer of 2007 by the Institute for Democracy and Mediation (IDM); $\mathrm{BiH}$, Croatia and Montenegro during the spring of 2008 by PULS; Albania and Kosovo during the summer of 2008 by IDM. Albania, BiH, Croatia, Macedonia, and Serbia each had a sample size of 1000 respondents, while Kosovo and Montenegro each had 500 respondents.

17 See Appendix A for full questionnaire.

18 We use the current term "Western Balkans" in this paper, but in the surveys and in interviews we asked about regional identity without using the term "Western Balkan" as we did not know how familiar the term would be. 
Surveys were conducted in local languages and with attention to local detail. Of particular concern was our desire to be sensitive to local context without losing the ability to compare across cases. Although our surveys were essentially standardized, we allowed our partnering agencies to suggest wording choices that most accurately and sensitively approached what we were attempting to discover. Despite the obstacles inherent in conducting research in the Western Balkans, we are confident that the data collected is valid and that it presents an accurate image of popular sentiment in the region.

\section{External Efforts in the Region}

International organizations have been heavily engaged in fostering the growth of a common "European" and well as "Balkan" identity. ${ }^{19}$ There has been a strategy by IOs, in particular the EU and NATO, to dangle the carrot of organization membership in front of the Western Balkans to encourage large-scale economic and political restructuring - the "stick" to the "carrot" of membership. Through this process, IOs are attempting to help create an environment where the norms of democracy can evolve. ${ }^{20}$

It is accepted among Euro-Atlantic elites that efforts to encourage democracy, and by presumed extension peace, must aim to increase and enhance interactions between IOs and potential allies to bring them into the Euro-Atlantic "in-group." EU and NATO officials have taken strides to communicate, cooperate and, where possible, collaborate with individual Western Balkan countries (territories). The EU, for example, determined that it would take an individual and a regional approach in its dealing with the countries of the Western Balkans. ${ }^{21}$ NATO is not as explicit in its requirements of regional cooperation, but favors those countries that have taken efforts to work with their regional neighbors. ${ }^{22}$

19 Due to the negative connotations sometimes associate with the term "Balkan" or "Balkanization," popularized in the 1990s, the label is rejected by some in the region. Croatia, the country most integrated into Euro-Atlantic institutions, in particular shuns the term "Balkan" with many preferring the less loaded "Southwestern Europe" (Author Interviews 2007-2008).

20 Our main interest in this paper is to learn more about public perceptions of communities within the Western Balkan region. This must start with a discussion of the important work of external actors, yet this is not the focus of our research. Literature exists on the role of the EU and NATO, and the process of conditionality in the Western Balkans (e.g. Bechev 2011; Grillot et al 2010).

21 Croatia, Macedonia and Montenegro are all currently EU candidate countries. It is anticipated that Croatia will be the first of the Western Balkan countries to join the Union, which could expand again as early as 2013 (Europa.com 2011).

22 The first two Western Balkan countries to join NATO, Croatia and Albania in 2009 were part of the Adriatic Charter. The Charter, created in 2003, was designed to institutionalize cooperation and assist in the membership aspirations of its members (originally Albania, Croatia and Macedonia). Today, Montenegro and Bosnia and Herzegovina are also participants (Rozoff 2009). 
These external parties have been important drivers in advancing regional cooperation, through EU and NATO conditionality. ${ }^{23}$

Although the process was not without many challenges, elites in the Western Balkans have shown remarkable political will to meet membership requirements in a relatively quick manner. This is evident in their increasing willingness to interact with one another and in their formal declarations of joint concern and cooperation. ${ }^{24}$ Our interviews in the region confirmed that elite-level interaction, and the early phases of elite-level security community, was occurring in large part due to the efforts of these external actors. ${ }^{25}$ For example government officials in Albania and Macedonia explained that they have joint concerns and goals. This is evident in their cooperative efforts to maintain the environmental integrity of Lake Ohrid, which sits between them. ${ }^{26}$ Officials we spoke to referred to not just their "friends in Europe" but also their partners in the "Western Balkans."

The dramatic increase in communication with not just IO representatives, but with other government officials is significant. It is clear that at the elite-level, there is recognition that regional cooperation is important for each country's individual integration into Euro-Atlantic institutions, as well as their security and economic prosperity in the future. However, what is not captured in these findings of elite interaction is how the populations living in the Western Balkans feel about others in their immediate neighborhood.

\section{Western Balkan Security Community and the Public}

The elite-level is an important starting place for understanding official security cooperation. Despite the positive and cooperative actions between Balkan governments, our interviews with average citizens in the region and our polling data present a disconnect. The development of public-level security community is much less apparent than the observed growth of security community among governing elites.

23 The global recession of late 2008 and 2009, the more recent Euro-crisis and the related "enlargement fatigue" within both the EU (and NATO to a lesser extent), mainly occurred after our research was conducted. Yet, these events and the growing financial anxiety of Euro-Atlantic institution members have surely served as negative drivers of regional cooperation and identity in recent years.

24 Simic 2011.

25 Grillot et al 2010; Author Interviews 2007-2008; Simic 2011.

26 UNEP 2011. 


\section{Western Balkan Regional Identity}

Adler suggests that security community in its nascent phase includes, positive interactions and thoughts of orientation toward neighboring communities. ${ }^{27}$ It is important that people feel a sense of community with their closest international partners. However, this should not exist at the expense of good regional relations. Recognition of a common Balkan identity among the seven Western Balkan countries (territories) would provide significant evidence of security community development among the public at the regional level.

Despite optimistic comments from elites in the region, few of those we interviewed among the general population viewed things in such positive terms. To be sure, most did comment that relations had improved for the better. However, many admitted that fear still exists and that among citizens there is minimal interaction across borders. For example, a young woman in Serbia indicated that she would never travel to Croatia because her friends who have previously done so faced unfriendly comments when they visited the country. ${ }^{28}$

Where there does appear to be evidence of regional identity is among ethnic populations living in different countries throughout the region. For example, citizens we spoke with in the Serbian section of Bosnia (Republika Srpska) indicated a strong affinity with their ethnic neighbors in Serbia. The migration patterns that developed during the Bosnian War left the Republika Srpska nearly entirely inhabited by ethnic Serbs. There is little interaction among them and the Bosniacs or even ethnic Croats who tend to live in the Federation of BiH. Likewise we spoke with some ethnic Albanians in Macedonia who feel a greater connection with Albanians in Albania as well as with the Albanian population of Kosovo than they do with ethnic Macedonians. ${ }^{29}$

In an attempt to go beyond our interviews, we used surveys to quantify the degree of public-level regional identity. Our surveys asked respondents with which region (Europe, the Western Balkans or some other) they felt most affinity. ${ }^{30}$ If regional security community is strong, we would expect a consistently high return of "Western Balkan" responses. On the other hand, if some sort of international identity dominates, we would see high percentages for "Europe" or perhaps even "other." A large number of respondents answering "both" would be optimal, indicating that both international and regional identity are developing.

27 Adler 1992; Adler 1991.

28 Author Interviews 2007-2008

29 Author Interviews 2007-2008

30 There are some who object to the Western Balkan label. Croatian in particular, are much more likely to use the term Southeastern Europe. Therefore, the survey question asked about other formerly Yugoslav countries, and Albania. 
Table 2: Your Country/Territory is Most Closely Tied to?

\begin{tabular}{|l|l|l|l|l|l|}
\hline & Europe/EU & $\begin{array}{l}\text { Western } \\
\text { Balkans* }\end{array}$ & Both & Other (US or Russia) & Do Not Know \\
\hline Albania & $71 \%$ & $17 \%$ & $7 \%$ & $1 \%$ & $5 \%$ \\
\hline $\mathrm{BiH}$ & $28 \%$ & $46 \%$ & $9 \%$ & $2 \%$ & $16 \%$ \\
\hline Croatia & $57 \%$ & $27 \%$ & $5 \%$ & $1 \%$ & $11 \%$ \\
\hline Kosovo & $37 \%$ & $2 \%$ & $2 \%$ & $60 \%$ & $\ldots$ \\
\hline Macedonia & $29 \%$ & $39 \%$ & $13 \%$ & $0 \%$ & $19 \%$ \\
\hline Montenegro & $33 \%$ & $50 \%$ & $15 \%$ & $0 \%$ & $1 \%$ \\
\hline WB Region**: & $42 \%$ & $30 \%$ & $9 \%$ & $11 \%$ **:* & $8 \%$ \\
\hline
\end{tabular}

"Understanding that "Western Balkans" is a new concept, surveyors used the term "region" or in some instances "former Yugoslavia"

** Unfortunately, Serbian respondents were not asked this question in a comparable manner

*** Kosovo was a major outlier on this question. "Do Not Know" was not an option.

As Table 2 shows, there is little consistency among Western Balkan populations. On average, the ties to the region appear much weaker than affinity with Europe. Of particular interest is Kosovo. Respondents from Kosovo answered overwhelmingly that they felt affinity with Europe and "other" regions. Kosovo's ethnic Albanians, much more than ethnic Serbs in Kosovo, cite affiliation with Europe. Unsurprisingly, ethnic Serbs in Kosovo were much more likely to cite ties to the Balkan region than ethnic Albanians were. Kosovo's long time classification as an international protectorate, likely accounts for this result.

Conversely, Montenegro and $\mathrm{BiH}$ had high percentages of their populations indicate that they felt affinity with the region. Montenegrins are possibly reacting to their new designation as an independent country. They remained tied to Serbia for much longer than the rest of the region, and when they decided to declare their independence in 2006, it was met with little violence. ${ }^{31}$ There was no significant difference in the response rates for those claiming to be Montenegrins and those in Montenegro who identify as ethnic Serbs.

Finally, $\mathrm{BiH}$ is comprised of three ethnic groups, two of which have strong allegiance to other countries (ethnic Croats and ethnic Serbs). This was borne out in the survey results. Additionally, the high "do not know" responses from Macedonia and $\mathrm{BiH}$, two countries with significant ethnic tensions, suggest that regional identities remain unclear in those instances. Therefore, although some countries (territories) respondents answered

31 "Montenegro" 2006. BBC. 
"Balkan" in significant numbers, the average for the region remained rather low and the results for "both," were just $9 \%$.

Given the mixed results surrounding regional identity, how is the noted increase in governmental interactions interpreted by citizens? Evidence suggests that many people do not believe the recent efforts at regional cooperation represent a genuine commitment toward working with their neighbors.

Table 3: Interethnic/Cross Border Relations in the Region are Based on:

\begin{tabular}{|l|l|l|l|}
\hline & Trust and belonging & Necessity and duty & Do not know \\
\hline Albania & $9 \%$ & $31 \%(49 \%$ "both")* & $11 \%$ \\
\hline BiH & $34 \%$ & $60 \%$ & $10 \%$ \\
\hline Croatia & $20 \%$ & $72 \%$ & $8 \%$ \\
\hline Kosovo & $57 \%$ & $36 \%$ & $6 \%$ \\
\hline Macedonia & $26 \%$ & $71 \%$ & $3 \%$ \\
\hline Montenegro & $28 \%$ & $70 \%$ & $1 \%$ \\
\hline Serbia & $44 \%$ & $42 \%$ & $13 \%$ \\
\hline WB Region & $35 \%$ & $54 \%$ & $7 \%$ \\
\hline
\end{tabular}

"Albanian survey takers allowed respondents to indicate "both," which does not conform to the format of the other surveys.

The majority of those surveyed felt that relations in the Western Balkan's region are based on "necessity and duty" (54 percent). In interviews, the reason for the "necessity and duty" of such interactions is generally perceived to be the result of encouragement from third parties. As mentioned, countries in the region want to join Euro-Atlantic institutions and have all taken steps to meet the requirements, which include efforts at regional cooperation. With this in mind, we asked survey respondents to indicate the level of cooperation they felt their countries should aim for with other others in the region. We also wondered about cooperation with the United States, Russia and in some cases, China.

While there are political reasons why cooperation might be deemed advantageous, Table 4 shows that old animosities persist. For example, respondents in Croatia and Kosovo did not think that their countries should have strong relations with Serbia. Kosovo and Serbia have an on-going debate over the status of Kosovo, and Croatia and Serbia have a history of tense relations. Likewise, Serbians did not appear eager to have their country cooperating with Croatia. 
Additionally, the two leaders of the region, Serbia and Croatia, have populations supporting only limited cooperation. Except for Croatians seeking cooperation with Bosnia, a country with significant numbers of ethnic Croats, Croatia and Serbia both gave rather low responses advocating for regional cooperation. On the other hand, the respondents from these two countries seem to favor cooperation with an outside player Croatia with the United States and Serbia with Russia. This may be a consequence of the EU policy of regional and bilateral approaches to membership. As membership nears, as it has for Croatia and by many accounts Serbia, the relationship with the EU becomes more important than cooperation with the region. ${ }^{32}$

Table 4: Rate the Level of Cooperation that Your Country Should achieve with:

\begin{tabular}{|c|c|c|c|c|c|c|c|}
\hline & Albania & $\mathrm{BiH}$ & Croatia & Kosovo & Macedonia & Montenegro & Serbia \\
\hline Albania* & -...- & 2.6 & 2.1 & 1.4 & 2.6 & 2.1 & 4.1 \\
\hline $\mathrm{BiH}$ & $66 \%$ & ..... & $81 \%$ & $68 \%$ & $84 \%$ & $76 \%$ & $76 \%$ \\
\hline Croatia & $38 \%$ & $64 \%$ & -..-- & $41 \%$ & $54 \%$ & $48 \%$ & $35 \%$ \\
\hline Kosovo & $77 \%$ & $65 \%$ & $59 \%$ & -...- & $73 \%$ & $56 \%$ & $20 \%$ \\
\hline Macedonia** & $68 \%$ & $84 \%$ & $84 \%$ & $65 \%$ & -...- & $61.2 \%$ & $65 \%$ \\
\hline Montenegro & $63 \%$ & $91 \%$ & $82 \%$ & $61 \%$ & $85 \%$ & -...- & $92 \%$ \\
\hline Serbia & $51 \%$ & $28 \%$ & $14 \%$ & $\mathrm{n} / \mathrm{a}^{*}$ & $44 \%$ & 37.6 & ....- \\
\hline
\end{tabular}

\begin{tabular}{|l|l|l|l|}
\hline & USA & Russia & China \\
\hline Albania* & 1.6 & 3.3 & Not asked \\
\hline BiH & $78 \%$ & $72 \%$ & $67 \%$ \\
\hline Croatia & $70 \%$ & $43 \%$ & $41 \%$ \\
\hline Kosovo & $84 \%$ & Not asked & Not asked \\
\hline Macedonia**: & $13 \%$ & Not asked & Not asked \\
\hline Montenegro & $80 \%$ & $88 \%$ & $72 \%$ \\
\hline Serbia & $13 \%$ & $57 \%$ & $45 \%$ \\
\hline
\end{tabular}

*Albanian responses were given as an average on a ratings scale, where $1=v e r y$ positive and $5=v e r y$ negative.

**Macedonian responses to this question for other Western Balkan countries were given as percentages of respondents who indicated confidence in the government of the country in question.

The results from these questions regarding identity formation within the Western Balkan region lead us to three observations. First, despite impressive elite-level interaction, a regional identity is not clearly apparent at the public-level. This supports our assertion

32 Mameli 2011. It is interesting that when Croatia joins the EU in 2013, it will have put up barriers to trade and cooperation with its neighbors in the region who are not members, hence counteracting the steps it was required to take (enhanced regional cooperation) to reach such membership. 
that elite-level security community has not trickled down in any consistent way to influence regional security community development. Second, our research highlights the continuing cynicism of many in the region. Generally, citizens see the actions of their governments as a means to an end. If citizens do not believe their governments feel a true connection with other countries in the region, it follows that many would not feel these connections with citizens in other communities either. It is also interesting that citizens in Croatia and Serbia, viewed as the two most significant countries in the region by the international community, seem to be the least interested in forming Balkan bonds. If the biggest players do not see the value in regional cooperation, there could be a problem for long-term peace in the region.

\section{Prospects for Peace}

In a security community partners orient positively toward each other and peaceful resolution of conflict is the norm. In regards to post-conflict peace in the Western Balkans, there once again seems to be a mixed result. During interviews, many in the region suggested that large-scale violence is improbable, not because the conditions for conflict have disappeared, but because the international community would not permit such events to happen again. However, this does not mean that all people in the region feel that conflict is in the past or that past conflicts have been handled properly. For peace to endure it must be facilitated and protected by those in the region, not simply by outside entities. Therefore, our survey included questions regarding prospects for peace.

Table 5: In Your Opinion, the Conflicts in the Region have been:

\begin{tabular}{|l|l|l|l|l|}
\hline & Successfully solved & $\begin{array}{l}\text { Solved but } \\
\text { unsuccessful / } \\
\text { temporary }\end{array}$ & $\begin{array}{l}\text { Have not been } \\
\text { solved at all }\end{array}$ & Don't know \\
\hline Albania* & $\ldots--$ & -- & -- & - -- \\
\hline BiH & $32 \%$ & $39 \%$ & $22 \%$ & $7 \%$ \\
\hline Croatia & $28 \%$ & $39 \%$ & $26 \%$ & $8 \%$ \\
\hline Kosovo & $16 \%$ & $35 \%$ & $44 \%$ & $5 \%$ \\
\hline Macedonia & --- & --- &.-- &.-- \\
\hline Montenegro & $33 \%$ & $50 \%$ & $13 \%$ & $4 \%$ \\
\hline Serbia & $5 \%$ & $46 \%$ & $44 \%$ & $5 \%$ \\
\hline WB Region & $22 \%$ & $42 \%$ & $30 \%$ & $6 \%$ \\
\hline
\end{tabular}

* Albania and Macedonia were not surveyed in a comparable manner

What is striking in Table 5 is the regionally consistent high response for "solved, but unsuccessfully." Interviewees at the public-level indicated that the resolution of past conflicts may not result in new violence, but would continue to stand in the way of regional 
(and internal) identity building for years to come. Our survey results corresponded to these interview findings.

Regarding the second question about conflict, there was more optimism. Again, the notion that the international community is paying attention to the smallest indicators of violence, likely influences this result. There does not appear to be much difference in how residents interpret the prospects for peace in the region as opposed to their individual countries. Macedonia is the one exception. This is probably due to the failure of Macedonia to receive an invitation to join NATO along with Albania and Croatia in 2008, and the on-going ethnic tensions in the country. As expected, the "do not know" numbers were highest in Kosovo. There were no significant differences along ethnic divisions throughout the region, though it is interesting to note that while agreeing that the future likely will hold peace and stability, Croatians (both in Croatia and in $\mathrm{BiH}$ ) and ethnic Serbs in the region were less optimistic than other ethnic groups.

Table 6: Do you feel that the upcoming years will bring peace and stability to your region/ country, or do you expect the return of violence?

\begin{tabular}{|l|l|l|l|l|l|l|}
\hline & \multicolumn{5}{|l|}{ Region } & \multicolumn{2}{l|}{ Country/Territory } \\
\hline & $\begin{array}{l}\text { Peace and } \\
\text { stability }\end{array}$ & Violence & Don't know & $\begin{array}{l}\text { Peace and } \\
\text { stability }\end{array}$ & Violence & $\begin{array}{l}\text { Do Not } \\
\text { know }\end{array}$ \\
\hline Albania* & & & & & & \\
\hline BiH & $67 \%$ & $17 \%$ & $16 \%$ & $67 \%$ & $19 \%$ & $14 \%$ \\
\hline Croatia & $61 \%$ & $28 \%$ & $11 \%$ & $64 \%$ & $27 \%$ & $8 \%$ \\
\hline Kosovo & $35 \%$ & $37 \%$ & $28 \%$ & $34 \%$ & $51 \%$ & $10 \%$ \\
\hline Macedonia & $68 \%$ & $21 \%$ & $10 \%$ & $52 \%$ & $23 \%$ & $26 \%$ \\
\hline Montenegro & $91 \%$ & $8 \%$ & $1 \%$ & $92 \%$ & $7 \%$ & $1 \%$ \\
\hline Serbia** & $56 \%$ & $30 \%$ & $14 \%$ & & & \\
\hline WB Region & $63 \%$ & $24 \%$ & $13 \%$ & $62 \%$ & $26 \%$ & $12 \%$ \\
\hline
\end{tabular}

"Albanian respondents were not asked this question as such.

**Serbians were asked the above question pertaining to the region only and not just for Serbia.

One of the most glaring issues that could hinder a lasting peace is the on-going struggle over Kosovo. ${ }^{33}$ Despite self-declared independence in February 2008, the status of Kosovo remains problematic. As events were happening, we asked respondents how they thought the declaration would affect the region.

33 The United States and a majority of EU countries were quick to recognize Kosovo's declaration of independence in 2008. The number of states extending recognition has grown, but the United Nations has yet to declare Kosovo as an officially recognized country ("Kosovo" 2012). 
Table 7: How do you Think Kosovo's Independence will Affect Relations in the Region?

\begin{tabular}{|l|l|l|l|l|}
\hline & Positively & Negatively & Neither & Do Not know \\
\hline Albania & $49 \%$ & $5 \%$ & $42 \%$ & $4 \%$ \\
\hline $\mathrm{BiH}$ & $35 \%$ & $38 \%$ & $15 \%$ & $13 \%$ \\
\hline Croatia & $53 \%$ & $31 \%$ & $6 \%$ & $1 \%$ \\
\hline Kosovo & $35 \%$ & $37 \%$ & $26 \%$ & $2 \%$ \\
\hline Macedonia* & $\mathrm{n} / \mathrm{a}$ & $\mathrm{n} / \mathrm{a}$ & $\mathrm{n} / \mathrm{a}$ & $\mathrm{n} / \mathrm{a}$ \\
\hline Montenegro & $12 \%$ & $64 \%$ & $15 \%$ & $5 \%$ \\
\hline Serbia* & $\mathrm{n} / \mathrm{a}$ & $\mathrm{n} / \mathrm{a}$ & $\mathrm{n} / \mathrm{a}$ & $\mathrm{n} / \mathrm{a}$ \\
\hline WB Region & $37 \%$ & $35 \%$ & $23 \%$ & $5 \%$ \\
\hline
\end{tabular}

*This question was asked in Macedonia and Serbia in 2007, before Kosovo's self-declared independence, and thus was worded differently. In Macedonia, the question was left as open ended and surveyors stated: "Believing that Kosovo will gain independence, respondents believe that once this problem is worked out, the region will have a significant leap forward." In Serbia, the question was phrased as "What is the best solution for the status of Kosovo?"

Not surprisingly, Serbian populations were more inclined to answer "negatively" than other ethnicities. Likewise, respondents from Albanian seem optimistic about the effect of Kosovo's declaration. Kosovars are pretty evenly split on the issue. Though not asked in their survey, Serbians we spoke with did not think that independence was going to positively affect regional relations, many suggested that Kosovo's "independence" would not be worth "Serbia going to war over."

Responses to these questions indicate the general feeling that the large-scale violence of the 1990s is not likely to return in the near future. However, it is clear that deep tensions still exist and that they could manifest in more contained instances of violence, and likely in the continued isolation of individual countries or ethnicities. If this continues, this will not bode well for the development of public-level security.

\section{Conclusions and Implications}

The research presented here provides evidence that elite-level security community does not necessarily (or quickly) lead to public-level security community. In the Western Balkans, public-level security community remains underdeveloped despite increased interaction and some signs of security community among governments. There remains significant distrust among populations and there is significant cynicism about the steps governments are undertaking to enhance regional cooperation.

34 Author Interviews 2007-2008. 
On a positive note, even though there is great dissatisfaction in how the conflicts of the past were resolved, few seem to think that large-scale conflict will erupt again in the near future. However, this belief does not stem from a public recognition that people in the region have common goals and concerns with their neighbors, but a sense that the international community will prevent such events from happening. Dependence on outside parties to keep the peace is perhaps not a positive development after all. The lack of regional community among the populations of the region will likely continue to stall efforts toward Euro-Atlantic integration.

Table 8: Elite and Public Regional Security Community Phases of Development

\begin{tabular}{|l|l|l|}
\hline & $\begin{array}{l}\text { Elite Level* } \\
\text { Security Community }\end{array}$ & $\begin{array}{l}\text { Public Level } \\
\text { Security Community }\end{array}$ \\
\hline Albania & Ascendant & Pre-Nascent \\
\hline Bosnia and Herzegovina & Nascent & Nascent \\
\hline Croatia & Ascendant & Nascent \\
\hline Kosovo & Nascent & Pre-Nascent \\
\hline Macedonia & Ascendant & Pre-Nascent \\
\hline Montenegro & Ascendant & Nascent \\
\hline Serbia & Nascent & Pre-Nascent \\
\hline
\end{tabular}

* See Grillot et al 2010, where we explore elite-level security community development. The 2010 piece is the basis for this part of the table.

\section{Frustration and Waning Attention}

Enhanced cooperation and the early developments of security community at the publiclevel will go a long way to assure the international community that the Western Balkans is a good bet. It will also be something for those in the region to fall back upon. This is especially significant now. With economic issues taking precedence among much of the Euro-Atlantic community, less attention has been paid to the Western Balkan region since 2008. There is now a sense of "Balkan fatigue" among EU elites, who see a lack of progress in the last five years. ${ }^{35}$ NATO's interest also seems to be waning as they view the Western Balkans as a project of Europeanization. ${ }^{36}$ Our research indicates that this diminishing concern for the region is a mistake. The Western Balkans cannot fall off the Euro-Atlantic radar. Internal tensions remain, frustrations continue and public-level security community is almost non-existence. A continued drawdown of Euro-Atlantic engagement could be detrimental to the region, and to the European continent itself.

35 Bieber 2012.

36 Ibid. 


\section{Building Security Community at the Public-level}

To encourage the development of regional, public-level, security community, we advocate for localized, community building efforts that with time can create an enhanced opportunity for public-level security community development in the Western Balkans region. First, given the interaction between governing officials, even the officials of countries with long standing disputes such as Serbia and Croatia, elites are in a unique situation to encourage and foster security community among the public. Governments need to encourage and foster greater interaction within and among their populations. Programs that incentivize partnerships between countries or ethnic groups should receive enhanced funding and attention from local governments. Likewise, travel should be encouraged and made as accessible as possible.

Second, media campaigns that promote commonality and solicit cooperation among the citizens of the region could also be an effective tool. While efforts were taken to highlight and take pride in differences after the breakup of Yugoslavia in the 1990s, now is the time to focus once again on similarities. This does not mean discouraging patriotism, and cultural pride, but encouraging regional identity.

Finally, the role of the international community is not over. The EU, NATO and the OSCE need to continue to encourage communication and cooperation at the elite-levels. They must also continue and strengthen their commitment to funding and supporting local community development projects, particularly those that aim to bridge ethnic and country divides through increased interaction and programing.

Attempts at building Balkan communities does not ensure the development of a regional, public-level security community, or a long-term peace. However, it is an important and significant way for the people of the Western Balkans to continue to move beyond the conflicts of the past to shape their own future. The international community is important and still needed it the region, however, now is the time for the people of the region to build Balkan communities. They must also work to deal with and discard past resentments to connect those communities at both the elite and most importantly, the public-level. 


\section{References}

Adler, Emanuel. 1991. "Cognitive Evolution: A Dynamic Approach for the Study of International Relations and Their Progress," In Progress in Postwar International Relations, edited by Emanuel Adler and Beverly Crawford, 291-92. New York: Columbia University Press.

Adler, Emanuel. 1992. “Europe’s New Security Order: A Pluralistic Security Community," In The Future of European Security, edited by Beverly Crawford, 287-326. Berkeley: University of California Press.

Adler, Emanuel and Michael Barnett. 1996. "Governing Anarchy: A Research Agenda for the Study of Security Communities," Ethics and International Affairs 10: 63-98.

Adler, Emanuel and Michael Barnett. 1998. "Security Communities in Theoretical Perspective," In Security Communities, edited by Emanuel Adler and Michael Barnett, 3-28. Cambridge: Cambridge University Press.

Adler, Emanuel and Michael Barnett. 1998. "A Framework for the Study of Security Communities," In Security Communities, edited by Emanuel Adler and Michael Barnett, 29-65. Cambridge: Cambridge University Press.

Belloni, Roberto. 2009. "European Integration and the Western Balkans: Lessons, Prospects and Obstacles," Journal of Balkan and Near Eastern Studies 11 (3): 313331.

Bechev, Dimitar. 2006. "Carrots, Sticks and Norms: the EU and Regional Cooperation in Southeastern Europe," Journal of Southern Europe and the Balkans 8 (1): 27-43.

Bechev, Dimitar. 2011. Constructing South East Europe: The Politics of Balkan Regional Cooperation. Houndmills Basingstoke: Palgrave Macmillan.

Bieber, Florian. 2012. “The Western Balkans are Dead - Long Live the Balkans!” In Unfinished Business - The Western Balkans and the International Community, edited by Verdran Dzihic and Daniel Hamilton. Washington DC: Brookings Institution.

Deutsch, Karl. 1957. Political Community and the North Atlantic Area. Princeton: Princeton University Press.

Deutsch, Karl W. 1964. "Communication Theory and Political Integration," In The Integration of Political Communities, edited by Philip E. Jacob and James V. Toscano, 46-74. Philadelphia: J.B. Lippincott Company. 
Grillot, Suzette R., Rebecca J. Cruise and Valerie J. D’Erman. 2010. “Developing Security Community in the Western Balkans: The Role of the EU and NATO," International Politics 47 (1): 62-90.

Kavalski, Emilian. 2006. "From the Western Balkans to the Greater Balkans Area: The External Conditioning of 'Awkward' and 'Integrated' States,' Mediterranean Quarterly 17 (3): 86-100.

Kavalski, Emilian. 2008. Extending the European Security Community: Constructing Peace in the Balkans. New York: Tauris Academic Studies.

\section{Europa.com 2011.}

“Kosovo Question Still Divides EU," 2012. Deutsche Welle. http://www.dw.de/dw/ article/0,,16226802,00.html

Mameli, Simona. 2011. "Regional Cooperation in the Western Balkans in Times of Political and Economic Uncertainty," Portal on Central Eastern and Balkan Europe. \#8. www.pecob.edu

“Montenegro Chooses Independence," 2006. BBC. http://news.bbc.co.uk/2/hi/ europe/5003220.stm

Simic, Predrag. 2011. "Euro-Atlanticism and the Creation of a Security Community' in the Balkans." Transconflict. http://www.transconflict.com/2011/07/ euroatlanticism-and-creation-of-security-community-balkans-117/

UNEP. 2011. http://www.worldlakes.org/lakedetails.asp?lakeid=8770

Rozoff, Rick. 2009. "Adriatic Charter and the Balkans: Smaller Nations, Larger NATO," Global Research. http://www.globalresearch.ca/adriatic-charter-and-thebalkans-smaller-nations-larger-nato/

Wendt, Alexander. 1992. "Anarchy is What States Make of It," International Organization 46 (2): 395-421. 
